\title{
Effects of omeprazole on neutrophil chemotaxis, super oxide production, degranulation, and translocation of cytochrome $b_{-245}$
}

\author{
J H Wandall
}

\begin{abstract}
The effects of omeprazole on polymorphonuclear neutrophil (PMN) chemotaxis, superoxide generation, degranulation and translocation of cytochrome $b_{-245}$ were investigated. Omeprazole $\left(10^{-6}-5 \times 10^{-3} \mathrm{~mol} / \mathrm{l}\right)$ reduced chemotaxis under agarose in a dose dependent manner, and the effect was irreversible. Superoxide anion generation was inhibited $50 \%$ at a concentration of $2.5 \times 10^{-5}$ $\mathrm{mol} / \mathrm{l}$ and completely abolished at $5 \times 10^{-3} \mathrm{~mol} /$ 1. Acid degraded omeprazole also inhibited $\mathrm{O}_{2}{ }^{-}$generation. Omeprazole did not scavenge $\mathrm{O}_{2}^{-}$generated in a cell free xanthin-xanthine oxidase system. Degranulation by PMNs was inhibited only by omeprazole in concentrations above $10^{-4} \mathrm{~mol} / \mathrm{l}$. Translocation of cytochrome $b_{-245}$, essential for generation of $\mathrm{O}_{2}^{-}$, was not affected by omeprazole. In conclusion, the anti-ulcer agent omeprazole in concentrations obtained during intravenous administration may inhibit the function of PMNs in vitro.
\end{abstract}

Omeprazole (5-methoxy-2-(((4-methoxy-3,5dimethyl-2-pyridinyl) me - thyl) sulphinyl)-1Hbenzimidazol) is a new anti-pulcer agent presently under extensive investigation. ${ }^{1-4}$ Omeprazole is an inhibitor of the $\mathrm{H}^{+}, \mathrm{K}^{+}$. ATPase in the secretory membrane of the parietal cell ${ }^{23}$ and accumulates by a mechanism that is dependent on the acid environment. ${ }^{+}$Only few other cells generate a low $\mathrm{pH}$ and one of these is the polymorphonuclear neutrophilic granulocyte (PMN).

Activation of PMNs by chemotactic factors or during phagocytosis is followed by metabolic activation, secretion of $\mathrm{H}^{+}$into the phagolysosome, and alkalinisation of the internal $\mathrm{pH}^{5-9}$ The response to activation depends on $\mathrm{H}^{+}, \mathrm{Na}^{+}$ exchange, phosphorylation of a membrane associated complex, ${ }^{10}$ and a membrane bound $\mathrm{H}^{+}$-ATPase. ${ }^{112}$ Translocation of a cytochrome $b_{-245}$ from granules to the membrane initiates nicotinamide-adenine-dinucleotide phosphate (NADPH)-oxidase activity and the production of super oxide anion $\left(\mathrm{O}_{2}^{-}\right)$and oxygen radicals assumed to be important for intracellular bacterial killing and tissue damage. ${ }^{13}$

It is possible that omeprazole can accumulate in PMNs and affect their function. The present investigation describes the effects of omeprazole on neutrophil function (chemotaxis, degranulation), production of $\mathrm{O}_{2}{ }^{-}$, and translocation of cytochrome $b_{-245}$ from the granules to the cell membrane.

\section{Methods}

Omeprazole was donated by B Wallmark (Hässle, Mölndal, Sweden). Dextrane T500 and Percoll were purchased from Pharmacia Fine Chemicals, formyl-methionine-leucinephenylalanine (FMLP), zymosan A, human and bovine serum albumin, ferricytochrome c (gr VI), cytochalasine $B$, superoxide dismutase, xanthine, xanthine oxidase, phenol-pthalaein$\beta$-gluronic acid, p-nitrophenyl phosphate NADH, sodium pyruvate, sodium hydrosulfite, piperazine-N'N-bis(2-ethane-sulfonic acid) (Pipes), EGTA, Mycobacterium lysodiekticus cell walls, human lysozyme, Coommassie brilliant blue G-250 were purchased from Sigma Chemical Co. Polyethylene glycol 400 was purchased from Fisher Chemical Co, agarose (Seakem ME) from Marine Colloids, Isolymph from Gallard and Schlesinger, and medium 199 and Hepes from Grand Island Biological Co.

\section{ISOLATION OF PMNS}

Buffy coats from healthy donors were mixed with dextrane to sediment the erythrocytes. The cells were collected from the leukocyte rich plasma by centrifugation $(100 \mathrm{~g} ; 10$ minutes; $4^{\circ} \mathrm{C}$ ), resuspended in $\mathrm{NaCl} 0.15 \mathrm{~mol} / \mathrm{l}$, and PMNs were purified on Isolymph gradients (360 g; 35 minutes). Residual erythrocytes were removed by hypotonic lysis (distilled $\mathrm{H}_{2} \mathrm{O}, 30$ seconds). The leukocytes were washed thrice and were resuspended in $\mathrm{Ca}^{++} \mathrm{Ma}^{++}$containing buffer $(\mathrm{Na}: 119 \mathrm{mmol} / \mathrm{l}$; K: $4 \cdot 7 \mathrm{mmol} / \mathrm{l}$; Ca: $0 \cdot 75$ $\mathrm{mmol} / \mathrm{l} ; \mathrm{Mg}: 1.2 \mathrm{mmol} / \mathrm{l} ; \mathrm{NaH}-\mathrm{PO}_{4} / \mathrm{H}_{2} \mathrm{PO}_{4}: 15$ $\mathrm{mmol} / \mathrm{l}$; glucose: $5 \cdot 5 \mathrm{mmol} / \mathrm{l} ; \mathrm{pH}: 7 \cdot 3$ ) or in medium $199(\mathrm{pH} 7 \cdot 3)$ with Hepes $25 \mathrm{mmol} / \mathrm{l}$ and human serum albumin $0.5 \mathrm{mg} / \mathrm{ml}$. The cell suspensions contained more than 95\% PMNs and more than $97 \%$ excluded tryphan blue.

\section{SOLUTIONS OF OMEPRAZOLE}

Omeprazole was dissolved in polyethylene glycol 400 (final concentration: $50 \mathrm{mmol} / \mathrm{l}$ ), aliquoted, and stored at $-70^{\circ} \mathrm{C}$. Omeprazole was thawed immediately before use, diluted with bicarbonate $0.75 \mathrm{mg} / \mathrm{ml}$ to $25 \mathrm{mmol} / \mathrm{l}$, followed by further dilution with $\mathrm{Ca}^{++} \mathrm{Mg}^{++}$containing buffer $(\mathrm{pH}$ $7 \cdot 3$ ), and was used within 30 minutes.

Acid degradation was done by the addition of hydrochloric acid $(0.01 \mathrm{~mol} / \mathrm{l}) 0.1 \mathrm{ml}$ to $0.9 \mathrm{ml}$ of $10^{-5}-10^{-3} \mathrm{~mol} / 1$ omeprazole $\left(37^{\circ} \mathrm{C} ; 15\right.$ minutes $)$. The $\mathrm{pH}$ was adjusted to $7 \cdot 3$ with Hepes buffer and the degraded omeprazole was kept on ice until used. of Medicine M 7721 Rigshospitalet, 20 Tagensvej, Copenhagen $2200 \mathrm{~N}$ Denmark.

Accepted for publication 30 August 1991 


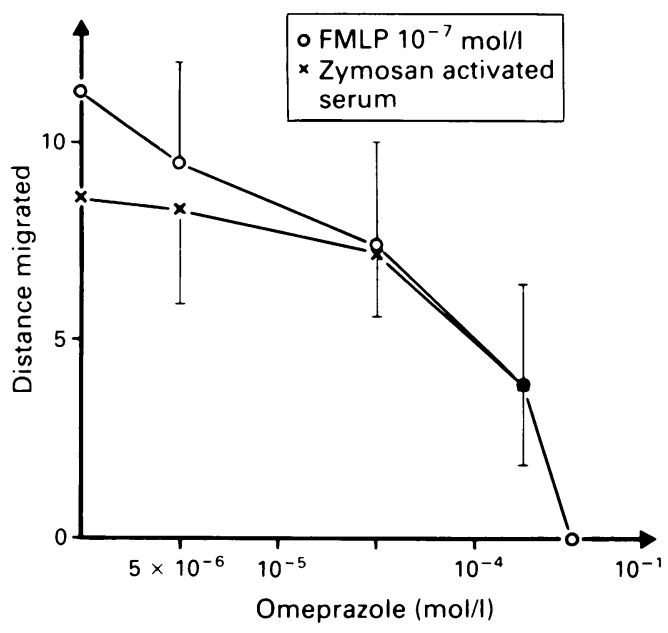

Figure 1: Chemotactic response by polymorphonuclear neutrophils incubated with varying concentrations of omeprazole. The distance migrated is given in arbitrary units. (Values mean (SD) of four experiments.) (FMLP = formylmethionine-leucine-phenylalanine.)

\section{ASSESSMENT OF PMN FUNCTION}

\section{Migration}

Migration and chemotaxis were studied by the agarose technique. ${ }^{1+}$ Agarose $(1 \%$ in medium 199; $\mathrm{NaHCO}_{3}: 400 \mu \mathrm{g} / \mathrm{ml}$; Hepes $25 \mathrm{mmol} / \mathrm{l}$; human serum albumin $0.5 \%$ ) containing omeprazole or solvent was layered on microscopic slides. Six rows of three wells were punched (d: $2.5 \mathrm{~mm})$. Chemoattractant (FMLP $10^{-7} \mathrm{~mol} / \mathrm{l}$; zymosan activated serum (ZAS)) or medium 199 was applied to the two lateral wells, and after 45 minutes. PMNs $\left(5 \times 10^{-5}, 10 \mu \mathrm{l}\right)$ in medium 199 were applied to the central well. The slides were incubated in a humified atmosphere $\left(90\right.$ minutes, $37^{\circ} \mathrm{C}, \mathrm{CO}_{2} 5 \%$ ). The slides were then fixed in glutaraldehyde $(2.5 \% ; 18$ hours), agarose was removed, and they were dryed. The distance migrated was measured after magnification $(\times 60)$ and the chemotactic response was given by the ratio between stimulated and unstimulated migration. Samples were measured in triplicate (interslide variation: 9\%; intraslide variation 7\%; no of experiments 12 ).

\section{Generation of $\mathrm{O}_{2}$}

Ferricytochrome c reduction was used to measure the generation of $\mathrm{O}_{2}^{-}{ }^{-}$. 15

PMNs in $\mathrm{Ca}^{++} \mathrm{Mg}^{++}$buffer were incubated with omeprazole $\left(30\right.$ minutes, $37^{\circ} \mathrm{C}$ ) followed by the addition of cytochalasine $B(2 \mu \mathrm{g} / \mathrm{ml})$. After five minutes the PMNs were isolated by centrifugation, resuspended in buffer without drug,

TABLE I Effect of degraded omeprazole on the chemotactic response of polymorph. The values given are percentages of untreated cells (median value of three experiments)

\begin{tabular}{llr}
\hline Concentration & FMLP $10^{7} \mathrm{moll} / \mathrm{l}$ & ZAS \\
\hline 0 & 100 & 100 \\
$5 \times 10^{5} \mathrm{~mol} / \mathrm{l}$ & 99 & 81 \\
$2.5 \times 10^{4} \mathrm{~mol} / \mathrm{l}$ & 70 & 67 \\
$5 \times 10^{-4} \mathrm{~mol} / \mathrm{l}$ & 46 & 53 \\
$1 \times 10^{3} \mathrm{~mol} / \mathrm{l}$ & 34 & 51
\end{tabular}

ZAS: zymosan activated serum. FMLP=formyl-methionineleucine-phenylalanine. and transferred to a cuvette with ferricytochrome c $(0.2 \mathrm{mmol})$ in $\mathrm{Ca}^{++} \mathrm{Mg}^{++}$buffer to a final volume of $1.0 \mathrm{ml}$. Incubations with appropriate concentrations of polyethylene glycol 400 served as controls. After the addition of FMLP $\left(10^{-7} \mathrm{~mol} / \mathrm{l}\right)$ the change in absorbance was followed in a dual beam spectrophotometer (Cary 15) with a reference cuvette containing ferricytochrome c, superoxide-dismutase (50 units $/ \mathrm{ml}$ ), and PMNs. The generation of $\mathrm{O}_{2}$ was calculated from the change in absorbance using a coefficient of $21 \mathrm{mM}^{-1} \mathrm{~cm}^{-1} .{ }^{16}$ The results are given as the percentage of PMNs incubated with solvent.

Assessment of $\mathrm{O}_{2}{ }^{-}$generation in a cell free system Scavenging of $\mathrm{O}_{2}{ }^{-}$by omeprazole was assessed in a xanthine-xanthine oxidase system. Reaction mixtures contained ferricytochrome c (25 $\mu \mathrm{mol})$, xanthine $(1 \mu \mathrm{mol})$, and xanthine oxidase $(0.2$ units $)$ in phosphate buffer $(0.12 \mathrm{~mol} / \mathrm{l}, \mathrm{pH}$ $7 \cdot 4$ ), omeprazole, or polyethylene glycol 400 . The reaction was initiated with xanthin-oxidase and the change in absorbance at $550 \mathrm{~nm}$ was followed in a dual beam spectrophotometer with a reference cuvette containing superoxide dismutase (100 units). The results are given as the percentage of incubations with solvents.

\section{Degranulation}

The release of glucuronidase (EC 3.2.31) and lysozyme (EC 3.2.1.17) by PMNs activated with FMLP was used to measure degranulation. ${ }^{17}$

PMNs $\left(1-3 \times 10^{7} / \mathrm{ml}\right)$ in $\mathrm{Ca}^{++}-\mathrm{Mg}^{++}$buffer were incubated with omeprazole or solvent $\left(37^{\circ} \mathrm{C} ; 30\right.$ minutes $)$, cytochalasine B $(2 \mu \mathrm{g} / \mathrm{ml})$ was added, and after five minutes FMLP $\left(10^{-}\right.$ $\mathrm{mol} / \mathrm{l})$. The reaction was stopped after 10 minutes by placing samples on ice. After centrifugation $\left(1000 \mathrm{~g}, 10\right.$ minutes $\left.4^{\circ} \mathrm{C}\right)$, the supernatant was assayed for enzymatic activity. Results are given as the percentage of activity released from unstimulated cells after sonication (Triton-x100 0.25\%; $3 \times 15$ seconds, Branson Inst).

Glucuronidase was determined by the release of phenolpthalein from phenolpthalein- $(\beta$ glucuronic acid $(1 \mathrm{mmol} / \mathrm{l}$ in acetate buffer $0 \cdot 1$ $\mathrm{mol} / \mathrm{l} ; \mathrm{pH} 4 \cdot 4) .{ }^{17}$ Lysozyme was measured as the decrease in absorbance at $450 \mathrm{~nm}$ of $M$ lysodiekticus cell walls $(0.2 \mathrm{mg} / \mathrm{ml}$ in phosphate buffer $0.062 \mathrm{~mol} / \mathrm{l}$; pH 6.2). ${ }^{18}$ Release of lactate dehydrogenase was followed as a marker of cell damage by the change in absorbance at $340 \mathrm{~nm}$ with sodium pyruvate as substrate.

\section{SUBCELLULAR FRACTIONATION}

\section{Incubation and activation of PMNs}

PMNs in $\mathrm{Ca}^{++} \mathrm{Mg}^{++}$buffer $\left(5-10 \times 10^{8}\right.$ cells) were incubated $\left(30\right.$ minutes, $\left.37^{\circ} \mathrm{C}\right)$ with omeprazole $\left(2.5 \times 10^{-4} \mathrm{~mol} / \mathrm{l}\right)$ or solvent followed by activation with FMLP $\left(10^{-7} \mathrm{~mol} / \mathrm{l} ; 15\right.$ minutes $)$. Unstimulated PMNs were kept as control. The reaction was stopped with ice cold buffer; PMNs were recovered by centrifugation and resuspended in relaxation buffer ${ }^{19}(\mathrm{KCl} 100$ 
$\mathrm{mmol} / \mathrm{l}, \mathrm{NaCl} 3 \mathrm{mmol} / \mathrm{l}, \mathrm{MgCl}_{2} 3 \cdot 5 \mathrm{mmol} / 1$, Pipes $10 \mathrm{mmol} / 1, \mathrm{pH} 7 \cdot 3)$.

\section{Disruption of PMNs}

PMNs in 8-10 ml relaxation buffer were pressurised with $\mathrm{N}_{2}\left(300\right.$ psi; 30 minutes; $4^{\circ} \mathrm{C}$ ) in a nitrogen bomb (Artisan, Waltham MA, USA) under stirring for the first 15 minutes. The cavitate was collected dropwise into EGTA ( $\mathrm{pH}$ $7 \cdot 4$ final concentration $1 \mathrm{mmol} / \mathrm{l})$. Unbroken cells $(25-35 \%)$ and nuclei were removed by centrifugation $\left(500 \mathrm{~g}, 15\right.$ minutes; $\left.4^{\circ} \mathrm{C}\right)$.

\section{Fractionation on Percoll gradients}

Fractionation was performed essentially as previously described. ${ }^{19}$ The supernatant from the cavitate was layered on a discontinuous gradient of $9 \mathrm{ml}$ Percoll (density $1.05 \mathrm{~g} / \mathrm{ml}$ ) layered on $9 \mathrm{ml}$ with density $1 \cdot 12 \mathrm{~g} / \mathrm{ml}$. After centrifugation (49000 g, 20 minutes; $4^{\circ} \mathrm{C}$; Beckman TI-60) three bands were visible and could be recovered by pipetting. Percoll was removed by centrifugation $(210000 \mathrm{~g}$; Beckman TI-50) and the material was resuspended in phosphate buffered saline.

\section{Spectroscopy}

Absorption spectra (440-600 nm; Cary 15) were measured after addition of triton $x-100(0 \cdot 2 \%)$. The samples were divided and solid sodium hydrosulphite (1-2 mg) was added to the sample cuvette. Cytochrome $b_{-245}$ was quantitated from the $559 \mathrm{~nm}$ peak using an absorption coefficient of $21.6 \mathrm{mM}^{-1} \mathrm{~cm}^{-1}, 20$ and myeloperoxidase from the $472 \mathrm{~nm}$ peak using an absorption coefficient of $75 \mathrm{mM}^{-1} \mathrm{~cm}^{-1}$.

\section{Miscellaneous}

Alkaline phosphatase (EC 3.1.3.1) was measured with p-nitrophenyl-phosphate as substrate (1 $\mathrm{mg} / \mathrm{ml}$ ) in $50 \mathrm{mmol} / \mathrm{l}$ sodium barbital buffer with $\mathrm{MgCl}_{2}, \mathrm{pH} 10 \cdot 5 .{ }^{22}$

Protein was measured as described by Bradford $^{23}$ with bovine serum albumin as standard.

\section{Results}

CHEMOTACTIC FUNCTION

Preincubation with omeprazole reduced the FMLP chemotactic response in a concentration dependent fashion (Fig 1). Omperazole reduced the distance migrated when both FMLP as well as ZAS were used as chemoattractants. Incuba-

TABLE II Distribution of marker proteins in fractions from Percoll gradients. Values given are percentages of total recovery from the gradients. (Values median (range) of four experiments)

\begin{tabular}{llll}
\hline & \multicolumn{4}{l}{ Fraction } & \\
\cline { 2 - 4 } & $A$ & $B$ & $C$ \\
\hline Alkaline phosphatase & $96(89-100)$ & $4(0-11)$ & 0 \\
Lysozyme & $2(0-3)$ & $55(43-76)$ & $39(22-49)$ \\
P-glucuronidase & $6(0-11)$ & $24(11-35)$ & $70(59-81)$ \\
Myeloperoxidase & $1(0-4)$ & $31(25-50)$ & $58(48-68)$ \\
\hline
\end{tabular}

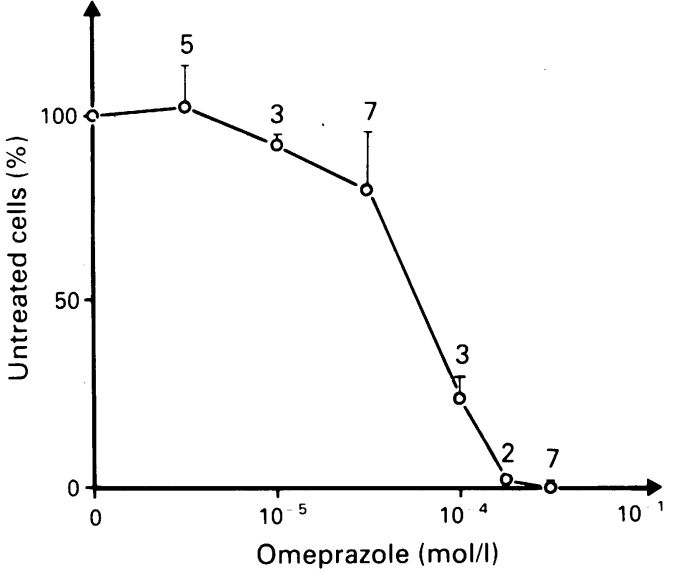

Figure 2: Production of $\mathrm{O}_{2}{ }^{-}$by polymorphonuclear neutrophils preincubated with omeprazole in varying concentrations and activated with FMLP $\left.10^{-7} \mathrm{~mol} / \mathrm{l}\right)$. (Values mean $(S D)$.)

tion with omeprazole $\left(5 \times 10^{-5}\right.$ and $10^{-4} \mathrm{~mol} / \mathrm{l}$; 30 minutes) and resuspension in media without omeprazole reduced the chemotactic index to $61-65 \%$ and $53-63 \%$ of untreated control cells $(\mathbf{n}=3)$. When acid degraded omeprazole was used a similar inhibition was observed (Table I).

\section{GENERATION OF $\mathrm{O}_{2}$}

PMN generation of $\mathrm{O}_{2}^{-}$was inhibited by omeprazole in a dose dependent manner (Fig 2). There was $50 \%$ inhibition $\left(\mathrm{IC}_{50}\right)$ at a concentration of $2 \cdot 5 \times 10^{-5} \mathrm{~mol} / \mathrm{l}$.

Varying the time that the PMNs were incubated with omeprazole from 10 to 50 minutes showed the effect to be maximal after 30 minutes (10 minutes: $82 \%$; 20 minutes: $62 \%$; 30 minutes: $35 \%$; 50 minutes: $34 \% ; \mathrm{n}=3)$ ).

Quenching of $\mathrm{O}_{2}^{-}$generated by omeprazole would mimick inhibition of ferricytochrome $c$ reduction. A cell free xanthine-xanthine oxidase system was used to assess the effect of omeprazole alone. In this system omeprazole did not scavenge the $\mathrm{O}_{2}^{-}$generated $\left(2 \times 10^{-4}-5 \times 10^{-4}\right.$

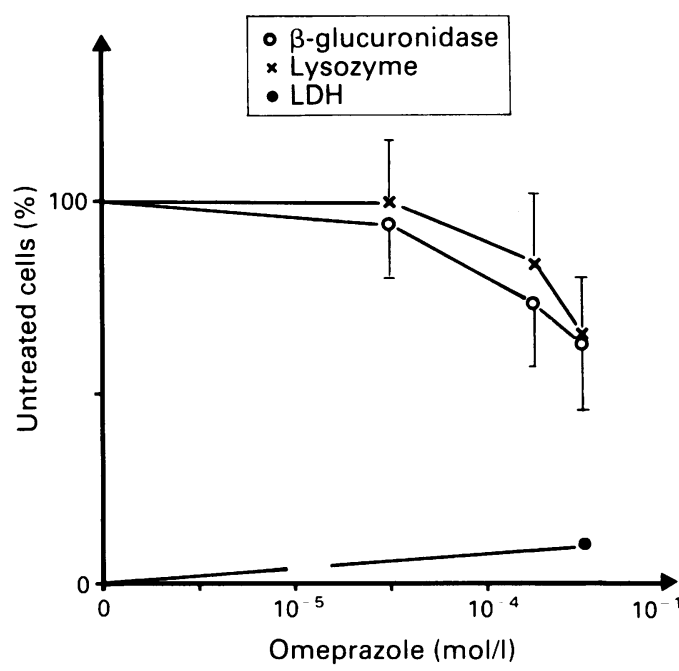

Figure 3: Release of lysozyme, $\beta$-glucuronidase, and lactate dehydrogenase ( $L D H)$ from FMLP stimulated

polymorphonuclear neutrophils preincubated with omeprazole in the concentrations indicated. (Values mean $(S D)$ of seven experiments.) 


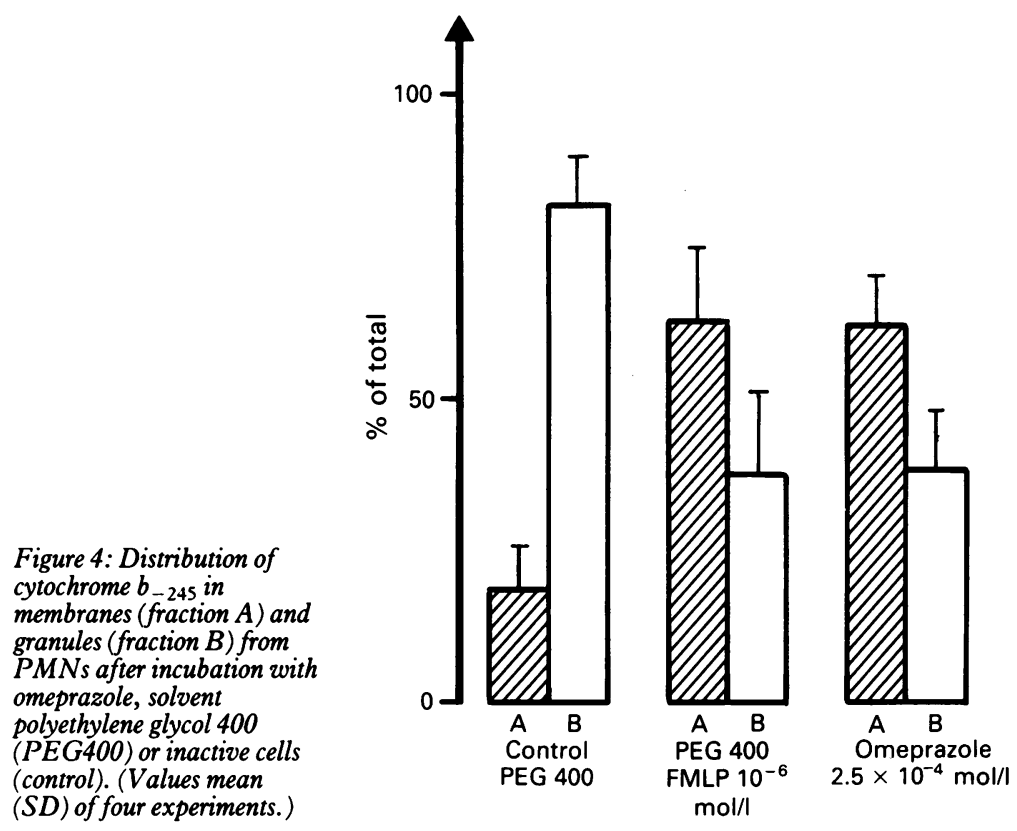

$\mathrm{mol} / \mathrm{l} ; \mathrm{O}_{2}{ }^{-}$generation: $101-106 \%$ of controls $(\mathrm{n}=3))$.

Generation of $\mathrm{O}_{2}^{-}$was also measured after incubation of PMNs with acid degraded omeprazole, imidazole, and 5.6-di-methyl-benzimidazole. Only acid degraded omeprazole $\left(10^{-5}-5 \times\right.$ $\left.10^{-4} \mathrm{~mol} / \mathrm{l}\right)$ was found to inhibit $\mathrm{O}_{2}^{-}$generation by 92 to $0 \%$ of control incubations. Imidazole or 5,6-di methylbenzimidazole had no effect in concentrations from $10^{-5}$ to $5 \times 10^{-4} \mathrm{~mol} / 1$.

DEGRANULATION OF PMNS

Preincubation with omeprazole followed by activation of PMNs showed a diminished liberation of enzymatic activity into the medium in concentrations above $10^{-4} \mathrm{~mol} / \mathrm{l}$. The marker for cell damage (lactate dehydrogenase) remained low (control: 6\% (range 5-8); omeprazole $5 \times 10^{-4} \mathrm{~mol} / \mathrm{l}$ : $5 \%$ (range 0-12) (Fig 3).

TRANSLOCATION OF CYTOCHROME $b_{-245}$

Nitrogen cavitation of PMNs and centrifugation on Percoll gradients results in three distinct bands. Table II gives the distribution of marker proteins. Fraction A contains the marker for membranes (alkaline phosphatase) and fractions $\mathrm{B}$ and $\mathrm{C}$ markers for granules ( $\beta$-glucuronidase, lysozyme, myeloperoxidase).

Spectroscopy of reduced versus non-reduced samples showed translocation of cytochrome $b_{-245}$ from the granule fraction to the membrane fraction after activation. Figure 4 depicts the distribution of cytochrome $b$ in resting, activated, and activated omeprazole treated PMNs. Incubation with omeprazole or polyethylene glycol 400 did not change the distribution of cytochrome $b_{-245}$.

\section{Discussion}

The present study found that omeprazole inhibits PMN chemotaxis, degranulation, and $\mathrm{O}_{2}{ }^{-}$generation in concentrations that can be observed after intravenous administration of omeprazole. ${ }^{2+}$ Similar studies have not been reported before. Omeprazole inhibited the response of PMNs in a concentration dependent fashion, with an $\mathrm{IC}_{50}$ of $2 \cdot 5 \times 10^{-5} \mathrm{~mol} / \mathrm{l}$. This is higher than the $\mathrm{IC}_{50}$ for the parietal cells $\left(\mathrm{IC}_{50}\right.$ : $\left.5 \times 10^{-6} \mathrm{~mol} / \mathrm{l}\right)$. The differences in the $\mathrm{IC}_{50}$ required to affect PMNs and the parietal cells make a clinical effect unlikely during peroral administration since the plasma concentrations are low. However, during intravenous administration concentrations of $1-2 \times 10^{-5} \mathrm{~mol} / \mathrm{l}$ are observed for a period of several hours. ${ }^{24}$ An effect in vivo is not unlikely considering the irreversibility of the in vitro effect observed in the present study.

Omeprazole is a substituted benzimidazole with a high affinity for intracellular compartments with an acid $\mathrm{pH} .{ }^{4}$ In the acid environment the drug degrades and the activity is associated with the degradation products. ${ }^{42}$ The mode of action is inhibition of the parietal cell $\mathrm{H}^{+}, \mathrm{K}^{+}$. ATPase, causing a diminished proton secretion into the secretory canaliculus. ${ }^{34}$

The reasons for the present study were: (1) the affinity of omeprazole for acid environment and (2) the acidification of the phagolysosome by a proton secreting mechanism in the activated PMN. ${ }^{6812}$ The mechanism of inhibition observed is probably an effect upon the PMN itself, since no effect could be demonstrated in a cell free system.

Increased oxidative metabolism and generation of $\mathrm{O}_{2}{ }^{-}$occur as early events in the activation of PMN. Omeprazole and its acid degradation products had a similar effect and it is probably the degradation products that are active. The acid degradation used in the present study results in generation of sulphanemid acid derivatives known to be active in the parietal cell. ${ }^{20}$ Inhibition by omeprazole and its degradation products and lack of effect in a cell free system or of related imidazoles indicate that a cellular mechanism is inhibited. The findings that a period of 30 minutes is required for maximal inhibition and that the effect is irreversible point to a cellular mechanism. Several mechanisms are possible.

Omeprazole has a high affinity for the glutathione-system ${ }^{25}$ and inhibition of the glutathione-system diminishes production of $\mathrm{O}_{2}^{-}$by PMNs. Inhibition of the NADPHoxidase or blocking the formation of the oxidase in the membrane itself may also have reduced $\mathrm{O}_{2}^{-}$generation.

Activation of PMNs is associated with formation of a dormant membrane associated a NADPH-oxidase by translocation of cytochrome $b_{-245}$ from the granules to the membrane. ${ }^{19}$ This translocation was not affected by omeprazole. A direct effect on the oxidase itself or on assembly of the oxidase in the membrane cannot be excluded. Imidazole in a high concentration $(30-50 \mathrm{mmol} / \mathrm{l})$ inhibits the oxidase ${ }^{26}$ but imidazole and 5.6.dimethyl-benzimidazole in low concentrations did not inhibit $\mathrm{O}_{2}{ }^{-}$generation.

Omeprazole may also inhibit ATPase in the PMN membrane. A quabain sensitive ATPase has been described for the PMN membrane by 
some $^{27}$ but the existence is disputed. ${ }^{15}$ During activation of PMNs an electroneutral proton secretion is activated. This includes an $\mathrm{Na}^{+} \mathrm{H}^{+}$ ATPase and there is evidence that this proton pump requires assembly of several components at the membrane. ${ }^{6712}$ The present study raises the possibility of common features between the proton pump in the parietal cell and in PMNs. It is noteworthy in this context that omeprazole inhibits another phagocyte - viz the osteoclast in vitro at an $\mathrm{IC}_{50}$ of $10^{-5} \mathrm{~mol} / 1 .^{28}$

In conclusion, a new anti-ulcer drug, omeprazole, has been shown to inhibit the functions of PMNs in concentrations that are reached during intravenous administration. Whether these findings have clinical importance remains to be studied in vivo. A beneficial implication of this study is that omeprazole may have an antiinflammatory activity.

The author is a Grove-Rasmussen fellow, Massachusetts General Hospital and Harvard Medical School. Dr William Beck kindly allowed me to use the clinical haematology laboratory and I am grateful for the support given by Charles Huggins MD, director of the Blood Transfusion Service. The study was supported by Lundbecks foundation and by K Høigaards foundation.

1 Lauritzen K, Rune SJ, Bytzer P, Kelbaek H, Jensen KG, Rask Madsen J, et al. Effect of omeprazole and cimetidine on duodenal ulcer. A double blind comparative trial. $N$ Englf Med 1985; 312: 958-61.

2 Fellenius E, Berglindh T, Sachs G, Olbe L, Elander B, Sjöstrand $S E$, et al. Substituted benzimidazoles inhibit gastric acid secretion by blocking $\left(\mathrm{H}^{+}+\mathrm{K}^{+}\right)$-ATPase Nature 1981; 290: 159-61.

3 Sachs G, Chang HH, Rabon E, Schakmann R, Lewin M, Saccomani GJ. A non-electrogeneic $\mathrm{H}^{+}$pump in plasma Saccomani GJ. A non-electrogeneic $\mathrm{H}^{+}$pump in plasma

4 Wallmark B, Brändström A, Larsson H. Evidence for acid induced transformation of omeprazole into an active inhibitor of $\left(\mathrm{H}^{+} \mathrm{K}^{+}\right)$-ATPase within the parietal cell. Biochim Biophys Acta 1984; 778: 549-58.

5 Styrt B, Klempner MS. Internal pH of human neutrophil lysosomes. FEBS Lett 1982; 149: 113-6.

6 Simchowitz $\mathrm{L}$. Chemotactic factor induced activation of $\mathrm{Na}^{+}$ $\mathrm{H}^{+}$exchange in human neutrophils. II. Intracellular $\mathrm{pH}$ changes. F Biol Chem 1985; 260: 13248-55.

7 Simchowitz $\mathrm{L}$. Chemotactic factor induced activation of $\mathrm{Na}^{+} /$ $\mathrm{H}^{+}$exchange in human neutrophils: I. Sodium fluxes. $\mathcal{F}$ Biol Chem 1985; 260: 13237-47.

8 Segal AW, Geisow M, Garcia R, Harper A, Miller R. The respiratory burst of phagocytic cells is associated with a rise in vacuolar $\mathrm{pH}$. Nature $1981 ; 290: 406-9$.

9 Hersko A, Cicckanover A. Mechanism of intracellular protein breakdown. Ann Rev Biochem 1082; 51: 335-64.
10 Nishikira J, O'Flaherty. Phorbol myristate acetate receptors in human polymorphonuclear neutrophils. F Immunol 1985 135: 3439-47.

11 Stone DK, Xie X-S, Racker E. An ATP driven proton pump in Clathrin-coated vesicles. F Biol Chem 1983; 258: 4059-62.

12 Mollinedo F, Schneider DL. Subcellular localization of cytochrome $\mathrm{b}$ and ubiquinone in a tertiary granule of resting human neutrophils and evidence for a proton pump ATPase. human neutrophils and evidence $1984 ; 259: 7143-50$.

13 Fantone JC, Ward PA. Polymorphonuclear leukocyte mediated cell and tissue injury: Oxygen metabolites and their relation to human disease. Human Pathol 1985; 16: 973-8.

14 Nelson RD, Quie PG, Simmons RL. Chemotaxis underagarose: A new and simple method for measuring chemotaxis and spontaneous migration of human polymorphonuclear leucocytes and monocytes. F Immunol 1975; 115 1650-6.

15 Borregaard N, Johansen KS, Esmann V. Quantitative superoxide production in human polymorphonuclear leucocytes from normals and 3 types of chronic granulomatous disease. Biochem Biophys Res Commun 1979; 90: 214-9.

16 Van Gelder BF, Slater EC. The extinction coefficient of cytochrome c. Biochim Biophys Acta 1962; 58: 593-5.

17 Brittinger G, Hirschhorn R, Douglas SD, Weissmann G. Studies on lysosomes XI: characteristics of a hydroxylaserich fraction from human lymphocytes. $\mathcal{F}$ Cell Biol $1968 ; 37$ $394-410$

18 Klass HJ, Hopkins J, Neale G, Peters TJ. The estimation of serum lysozyme: A comparison of four assay methods. Biochem Med 1977; 18: 52-7.

19 Borregaard N, Heiple JM, Simons ER, Clark RA. Subcellular localization of the b-cytochrome: Component of the human neutrophil microbicidal oxidase: translocation during activation. F Cell Biol 1983; 97: 52-61.

20 Cross AR, Higson FK, Jones OTG, Harper AM, Segal AW The enzymatic reduction and kinetics of oxidation of cytochrome $b_{-245}$ of neutrophils. Biochem $\mathcal{F}$ 1982; 204: 479 85 .

$21 \operatorname{Bos} \dot{A}$, Wever R, Roos D. Characteristics and quantification of the peroxidase in human neutrophils. Biochim Biophys Acta 1978; 525: 37-44.

22 DeChatelet IR, Cooper MR. A modified procedure for the determination of leucocyte alkaline phosphatase. Biochem Med 1970; 4: 61-8.

23 Bradford MM. A rapid and sensitive method for quantitation of microgram quantities of protein utilising the principle of protein dye binding. Anal Biochem 1976; 72: 248-54.

24 Lind T, Moore M, Olbe L. Intravenous omeprazole: effect on 24-hour intragastric $\mathrm{pH}$ in duodenal ulcer patients. Digestion 1986; 34: 78-86

25 Lindberg $P$, Nordberg $P$, Alminger T, Brändström A, Wallmark $B$. The mechanism of the gastric acid secretion inhibitor omeprazole. $\mathcal{F}$ Med Chem 1986; 29: 1327-9.

26 Iizuka T, Kanegasaki S, Makine R, Tanaka T, Ishimura Y. Pyridine and imidazole reversibly inhibit the respiratory burst in porcine and human neutrophils: Evidence for the involvement of cytochrome $b_{-558}$ in the reaction. Biochem Biophys Res Commun 1985; 130:621-6.

27 Klempner MS, Mikkelsen RB, Corfman DH, AndreSchwartz J. Neutrophil plasma membranes I: High-yield purification of human neutrophil plasma membrane vesicles purification of human neutrophil plasma membrane vesicles Biol $1980 ; 86: 21-8$.

28 Tuukkanen J, Väänänen HK. Omeprazole, a specific inhibitor of $\mathrm{H}^{+}-\mathrm{K}^{+}$-ATPase, inhibits bone resorption in vitro. Calcif Tissue Int 1986; 38: 123-5. 